\title{
Statyba
}

\section{AN EXPLORATION OF HEAT CONSUMPTION FOR PRODUCTION OF DOMESTIC HOT WATER IN CENTRAL HEAT SUBSTATIONS}

\section{E. Tuomas \& A. Skrinska}

To cite this article: E. Tuomas \& A. Skrinska (1998) AN EXPLORATION OF HEAT CONSUMPTION FOR PRODUCTION OF DOMESTIC HOT WATER IN CENTRAL HEAT SUBSTATIONS, Statyba, 4:3, 196-201, DOI: 10.1080/13921525.1998.10531404

To link to this article: https://doi.org/10.1080/13921525.1998.10531404

Published online: 26 Jul 2012.

Submit your article to this journal $\llbracket$

Џ Article views: 42 


\title{
AN EXPLORATION OF HEAT CONSUMPTION FOR PRODUCTION OF DOMESTIC HOT WATER IN CENTRAL HEAT SUBSTATIONS
}

\author{
E. Tuomas, A. Skrinska
}

\section{Introduction}

The biggest part of users in Vilnius satisfy their needs for heat from the district heating system [1]. The heat is supplied in two ways: directly into buildings and via central heat substations (CHS). The second scheme is widely used. In Vilnius over $170 \mathrm{CHS}$ are installed. In this case the hot water is supplied from the heat source to CHS by a twofold pipe system and further from CHS to users by a fourfold pipe system. According to this scheme, the heat medium (hot water from district heating network) breaks up into two flows [2]. One of them is for heating of buildings, and the other for production of domestic hot water. It should be emphased that for heating of premises and for production of domestic hot water the same heat medium from district heating is used.

Most of the heating systems of buildings in Vilnius are connected to the district heating system directly, ie the heat medium from district heating flows directly into the heating system of buildings. Vilnius City is located on a hilly relief and the district heating network follows the earth surface. Due to such a relief, water pressure in the district heating network can be less or over the permissible limit and it is dangerous, especially for heating systems of buildings. To avoid such problem in district heating of Vilnius 16 pump stations keeping required hydraulic regime are installed.

District heating system is closed in Vilnius and therefore in the process of production of domestic hot water, the water from district heating network is used as a heat medium. Domestic hot water is mostly produced in tube and shell heat exchangers by the heat supplied from the district heating system. The heat exchangers are installed in CHS. In such a case, heat consumption for the production of domestic hot water from the technical point of view is very closely connected with the heating of bathrooms when they are heated by towel rails. The towel rails get the heat from the same domestic hot water. Therefore, the problem of heat consumption for the production of domestic hot water can not be analysed separately from the heating system. Under the above-mentioned circumstances, the problem was investigated experimentally in one of CHS. During this investigation heat distribution, heat transfer and heat losses were established. Also, the parameters of hot domestic water were analysed.

The CHS located in Lazdynai (a district of Vilnius) was chosen as the subject of investigation.

\section{Method of analysis}

The central heat substation in a district of Vilnius and all buildings to which heat and hot water were supplied from that substation were chosen as a subject of analysis.

The thermal water in central heat substation breaks up into two flows: for heating of buildings and domestic hot water production. The water for heating is supplied to individual heat substations by pipes installed in passable ducts. Temperature of thermal water is not changed except for a natural drop due to the heat losses between the heat source and heat substation of the user. In the latter, temperature of the thermal water is reduced by jet pump. The thermal water is cooled in the heating system and returns to 
the central substation. There it is mixed with thermal water from heat exchangers and directed to the main of district heating.

Hot water is produced in instantaneous tubular heat exchanger, which consists of two stages and then is supplied to the buildings as thermal water by pipes installed in the same ducts. Part of the hot water is used for domestic purposes and the rest, as a circulating one, is returned to the second stage of heat exchanger in central heat substation. The cycle is over.

Flow rates of thermal, hot and cold water, amount and flux of heat transported by them were metered and recorded. The total flow rate was metered by PREMA WP 125 type flowmeter. The flow rates for heating and circulating hot water were metered by PREMA WS 80 type flowmeters. Heat amount was fixed by stationary integrators at these meters as a product of flow rates and temperature differences. The mentioned flow rates of heat mediums were also recorded by MITEC AT 40 data loggers. Temperature was measured by MU-TE 100 sensors and signals of pulses were sent by pulse cables MUDP 100. All parameters were fixed every $3 \mathrm{~min}$ and their average values were recorded every $15 \mathrm{~min}$ in a memory of data loggers. Flow rate of cold water was metered by CTBГ-1-100 meter. Outside air temperature was recorded every $30 \mathrm{~min}$ by Tinytalk II data logger at the same period. The parameters of thermal water in individual heat substations of buildings were fixed by stationary heat meters of different types. The flow rates of hot and circulating water were measured also by stationary installed flowmeters and temperature by Tinytalk II data loggers with Pt-100 sensors.

All data from metering equipment (amount of water, transported heat amount, duration of period between readings) were recorded at the same moment (5 min accuracy) in the central heat substation and individual heat substations of buildings. The total amount of thermal water $\mathrm{G}_{\mathrm{T}}$ and the heat amount $\mathrm{Q}_{\mathrm{T}}$ that was transferred by that thermal water as well as the amount of water $\mathrm{G}_{\mathrm{H}}$ and of heat $\mathrm{Q}_{\mathrm{H}}$ for buildings heating was measured. The pulse cables and temperature sensors of the above-mentioned data loggers were used in parallel to get the data about the regime of use. The difference of readings gave an amount of thermal water for production of domestic hot water $\left(G_{T H W}=G_{T}-G_{H}\right)$ and transferred amount of heat by it $\left(\mathrm{Q}_{\mathrm{THW}}=\mathrm{Q}_{\mathrm{T}}-\mathrm{Q}_{\mathrm{H}}\right)$. The amount of hot water produced for domestic purposes was kept equal to the amount of cold water which was fixed by meter M4 and supplied to a heat extender $\left(G_{H W}=G_{C W}\right)$. Temperature of hot water was being recorded by data logger permanently. The amount of water $\mathrm{G}_{\mathrm{CRW}}$ in circulating circuit and the heat losses $Q_{\mathrm{CRW}}$ in it was fixed. According to the amount of heat which was transferred from thermal water to the domestic hot water, heat needs for $1 \mathrm{~m}^{3}$ production of domestic hot water was established:

$$
\mathrm{q}_{\mathrm{THW}}=\mathrm{Q}_{\mathrm{THW}} / \mathrm{G}_{\mathrm{HW}} \text {. }
$$

Lost heat in circulating circuit for $1 \mathrm{~m}^{3}$ production of domestic hot water was calculated:

$$
\mathrm{q}_{\mathrm{LHW}}=\mathrm{Q}_{\mathrm{CRW}} / \mathrm{G}_{\mathrm{HW}} \text {. }
$$

For control of experimental data, the amount of heat needed to produce $1 \mathrm{~m}^{3}$ of domestic hot water was found:

$$
\mathrm{q}_{\mathrm{HW}}=\left(\mathrm{Q}_{\mathrm{THW}}-\mathrm{Q}_{\mathrm{CRW}}\right) / \mathrm{G}_{\mathrm{HW}} \text {. }
$$

This amount of heat was compared with theoretically calculated amount according to the equation (4):

$$
\mathrm{q}_{\mathrm{HW}}^{\mathrm{I}}=\mathrm{c}\left(\mathrm{t}_{\mathrm{HW}}-\mathrm{t}_{\mathrm{CW}}\right) \text {, }
$$

where: c - specific heat of water, $\mathrm{kJ} /\left(\mathrm{kg} \cdot{ }^{\circ} \mathrm{C}\right) ; \mathrm{t}_{\mathrm{HW}}$ - temperature of hot water, ${ }^{\circ} \mathrm{C} ; \mathrm{t}_{\mathrm{CW}}$ - temperature of cold water, ${ }^{\circ} \mathrm{C}$.

According to the readings of heat meters in individual heat substations, the amount of heat for heating of each building $Q_{B}$ was established during the investigation. The total amount of heat for heating of buildings $\Sigma Q_{B}$ was compared with the amount of heat for heating $\mathrm{Q}_{\mathrm{H}}$ which was measured in the central heat substation. The differences of these results, calculated according the formula

$$
\mathrm{Q}_{\mathrm{NHL}}=\left[\left(\mathrm{Q}_{\mathrm{H}^{-}}-\Sigma \mathrm{Q}_{\mathrm{B}}\right) / \mathrm{Q}_{\mathrm{H}}\right] \mathrm{X} 100
$$

gave the percentage of heat losses in distribution district heating network between the central heat substation and buildings. The ratio between the amount of hot and circulating water gave a possibility to find average needs of hot water per person per day. 


\section{Investigation results}

The variation of temperatures of supply and return hot water from district heating and its flow rate can be seen in Fig 1.

The diagrams show that during the investigation the flow rate was almost constant and the temperatures varied due to the qualitative regulation in heat source - combined heat and power station (CHP). The heat medium (hot water from district heating network) after it reached CHS breaks up into two flows.
One of them for heating of buildings and another for production of domestic hot water. The distribution of these two flows and their variation for a time is presented in Fig 2.

Heat flux for production of domestic hot water significantly varies during the day and the character of this variation is similar for all days. The total heat flux in the main corresponds to the nature of the heat flux for production of domestic hot water (Fig 2).

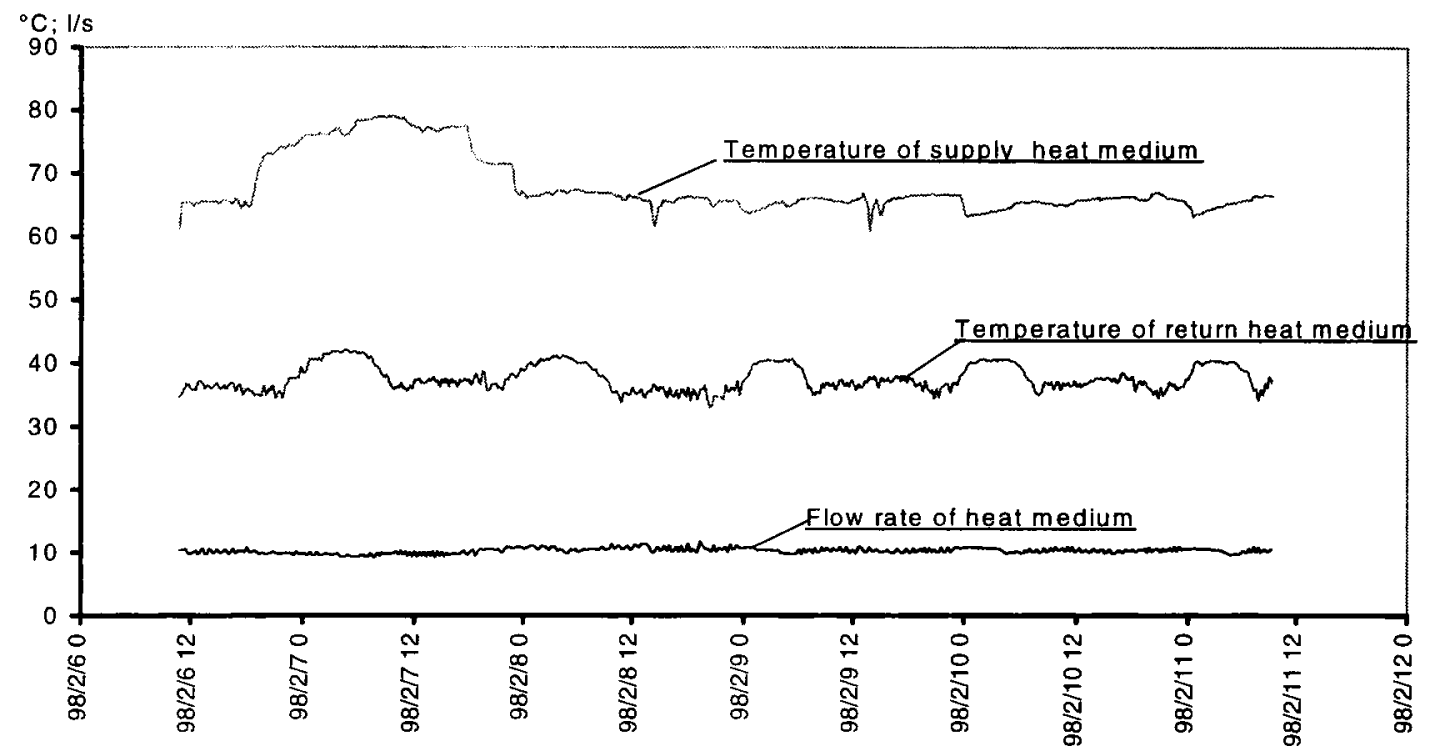

Fig 1. Flow rate and temperature of heat medium

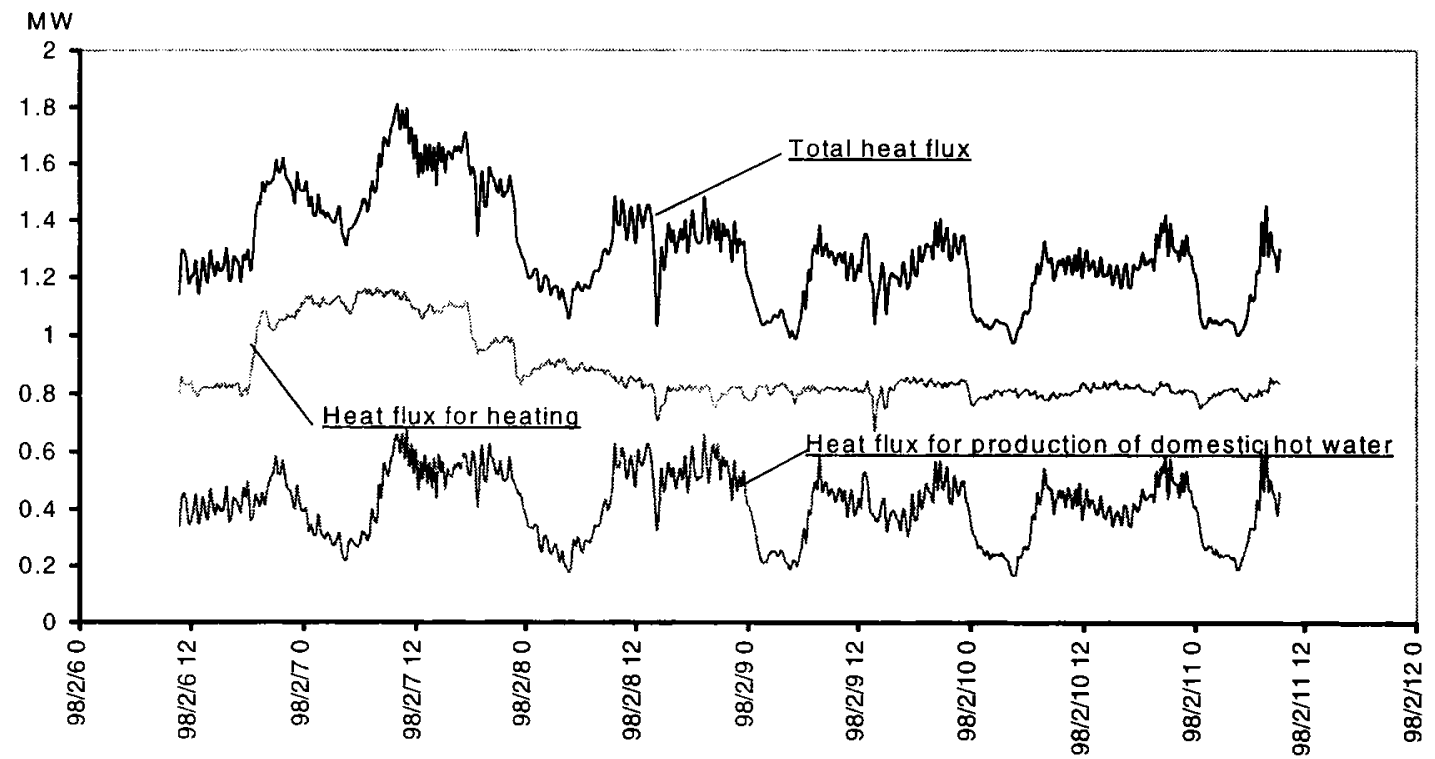

Fig 2. Heat fluxes in CHS 
The flow rates carrying the mentioned above heat fluxes as seen from Fig 3 are not equal. The biggest part (over 60\%) is used for heating and the rest for producing domestic hot water. The ratio of these fluxes is not constant. Flow rate for heating should be constant according to the condition of qualitative controlling but it is not because the mentioned condition is broken very often. Flow rate for production of domestic hot water varies according to variation of supply heat medium temperature. The variation of total heat medium flow rate was about $\pm 10 \%$.
Consumption of domestic hot water as seen from Fig 4 varies during the day and significantly increases at about 8 a.m. and considerably decreases at about 12 p.m. Domestic hot water consumption fluctuate on a very large scale. The ratio between the upper and lower limit varies during the all day up to 10 times. From the daily consumption data we have an average consumption of domestic hot water between 50 and 75 1 per person per day. The real energy consumption for domestic hot water production (Table 1) during different periods was investigated.

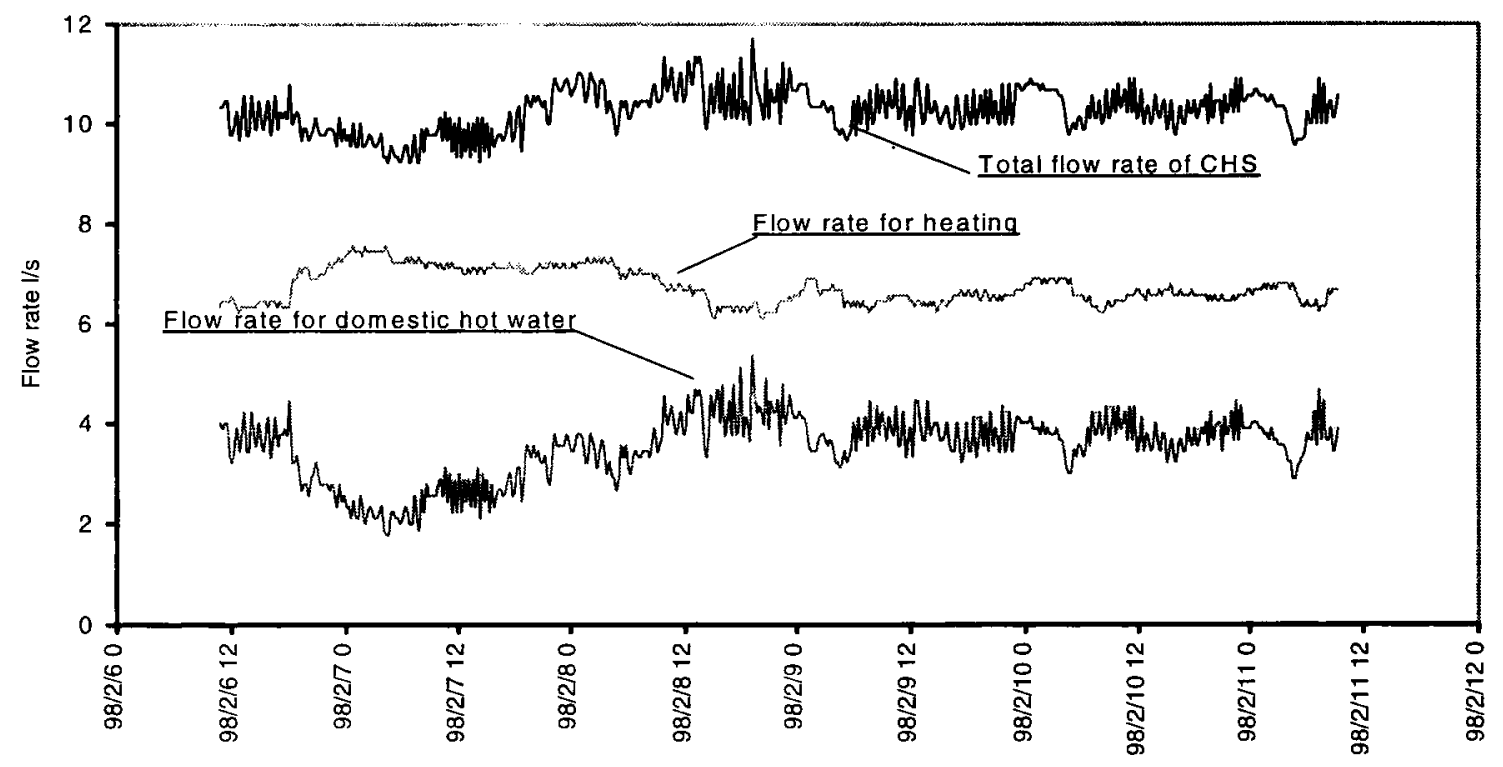

Fig 3. Flow rates of heat medium

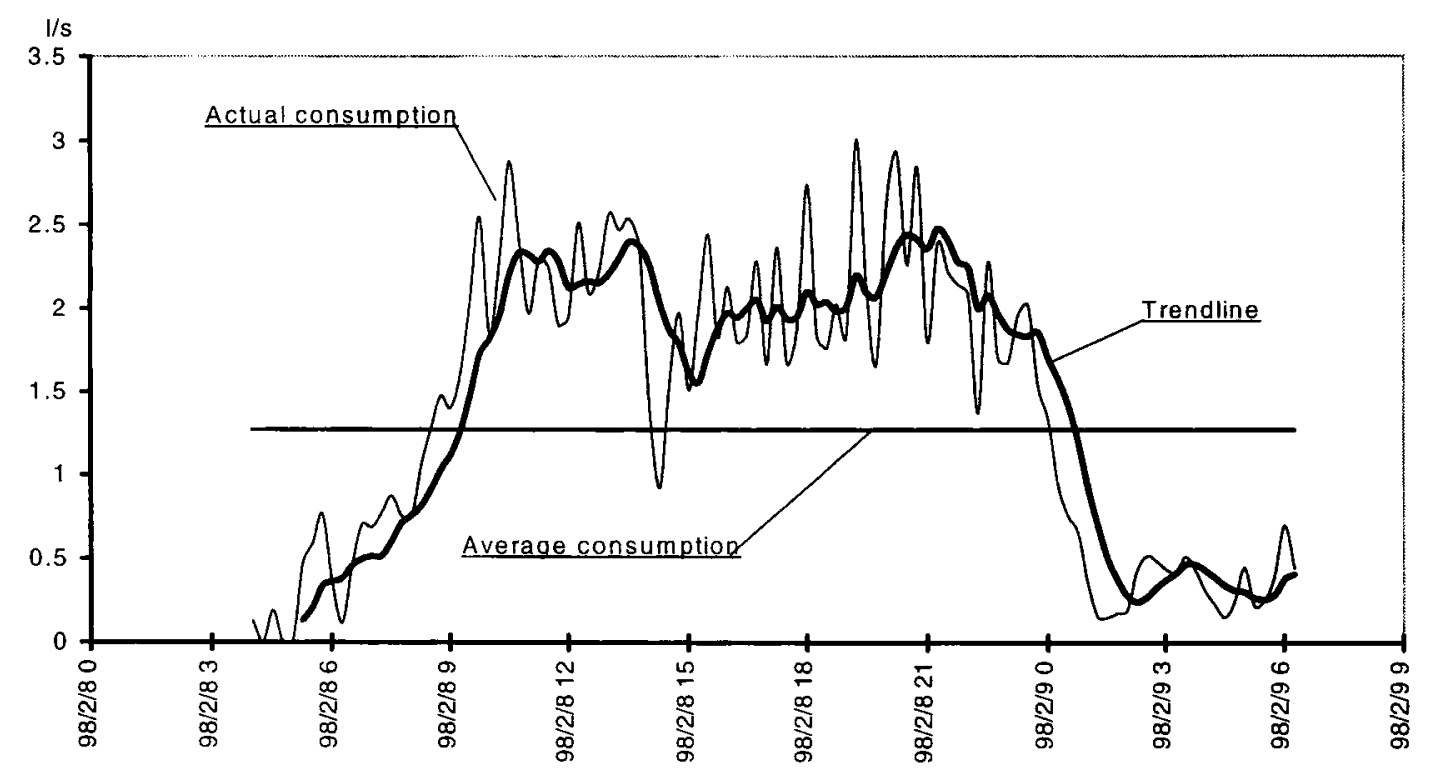

Fig 4. Daily consumption of domestic hot water 
Table 1. Heat consumption for hot domestic water

\begin{tabular}{|c|c|c|c|}
\hline \multirow{2}{*}{$\begin{array}{c}\text { Periods of } \\
\text { investigation }\end{array}$} & $\begin{array}{c}\text { Amount of } \\
\text { supplied domestic } \\
\text { hot water, } \mathrm{m}^{3}\end{array}$ & $\begin{array}{c}\text { Total } \\
\text { GJ }\end{array}$ & $\begin{array}{c}\text { For unit of pro- } \\
\text { duction, } \mathrm{kWh} / \mathrm{m}^{3}\end{array}$ \\
\cline { 3 - 4 } & 816,9 & 271,0 & 92,15 \\
\hline $19971202.15: 40-19971209.16: 00$ & 1121,1 & 412,0 & 102,28 \\
\hline $19971209.16: 00-19971219.15: 40$ & 1215,3 & 401,3 & 91,26 \\
\hline $19971219.15: 40-19971229.16: 45$ & 3410,4 & 1158,0 & 94,34 \\
\hline $19971229.16: 45-19980128.13: 00$ & 1582,1 & 595,1 & 104,48 \\
\hline $19980128.13: 00-19980211.10: 15$ & & & \\
\hline
\end{tabular}

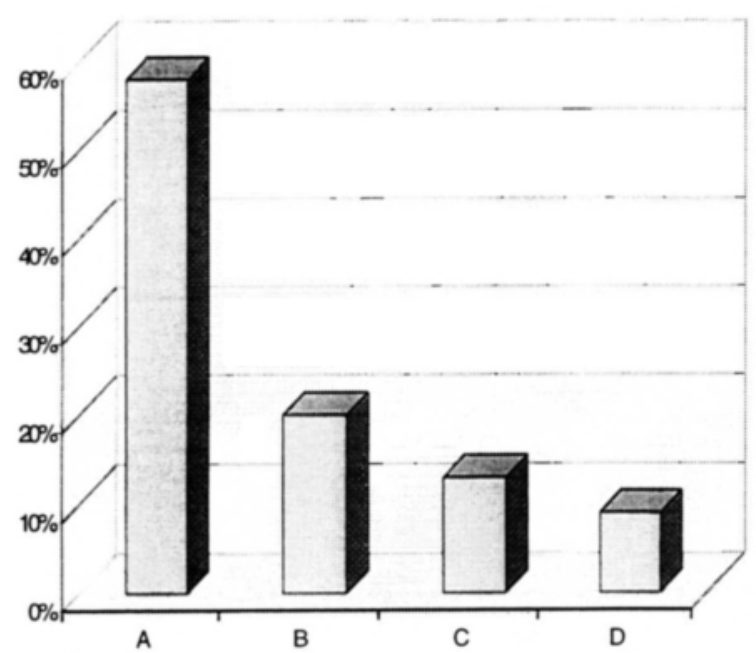

Fig 5. Energy consumption distribution for domestic hot water production: A - for heating of water; B - heat losses in domestic hot water mains; $\mathrm{C}$ - for heating of bathrooms; $\mathrm{D}$ heat losses in buildings

By measurements of heat consumption from $91,26 \mathrm{kWh} / \mathrm{m}^{3}$ up to 104,48 , an average result 96.75 was established. The theoretical consumption according to the (4) equation should be $56,53 \mathrm{kWh} / \mathrm{m}^{3}$. The difference of $40,22 \mathrm{kWh} / \mathrm{m}^{3}$ is lost in domestic hot water supply, distribution and circulation system. Experimentally the following percentage distribution of heat consumption for domestic hot water was found. Hot water production - 58\%; heat losses in supply and circulating pipes - $20 \%$; heat emitted by towel rails 13\%; heat losses in buildings (mains and risers) - 9\%. These figures are expressed graphically (see Fig 5).

\section{Conclusions}

1. Energy consumption was investigated in a group of buildings to which heat was supplied from the central heat substation (CHS) and domestic hot water was produced for them in the same CHS.

2. Energy consumption for domestic hot water production was established experimentally and it was during the different periods between 91 and 104 $\mathrm{kWh} / \mathrm{m}^{3}$, the average meaning $96.7 \mathrm{kWh} / \mathrm{m}^{3}$.

3. The following energy consumption distribution was established for domestic water heating from 9 up to $52.5 \mathrm{r} \mathrm{C}-56.5 \mathrm{kWh} / \mathrm{m}^{3}$ or $58.4 \%$; for heating of bathrooms by towel rails $-12.5 \mathrm{kWh} / \mathrm{m}^{3}$ or $12.9 \%$; heat losses in domestic hot water mains (supply and circulating) $-19.1 \mathrm{kWh} / \mathrm{m}^{3}$ or $19.8 \%$; heat losses in the mains and uninsulated risers of buildings $8.6 \mathrm{kWh} / \mathrm{m}^{3}$ or $8.9 \%$.

4. The heat losses in the distribution district heating network were $2.4 \%$ of the amount of heat transported during the investigation period.

5. The amount of domestic hot water was established per person per day. In separate buildings it was from 50 up to 751.

6. The character of variation of domestic hot and circulating water parameters was recorded during a long continuous investigation.

\section{References}

1. The review of the activities of the joint stock company "Lietuvos energija" in 1995. Vilnius: AB "Lietuvos energija", 1996.

2. E. Tuomas. Exploration of District Heating Networks // Heating and Air-Conditioning of Buildings. Energy and Environment: Proceedings of the Third SITHOK-3 International Congress, May 09-11, 1998 Maribor, Slovenia, p. 279-285.

Iteikta 19980220 


\section{ŠILUMOS SĄANAUDU TYRIMAS KARŠTAM VANDENIUI RUOŠTI CENTRINIUOSE ŠILUMOS PUNKTUOSE}

\section{E. Tuomas, A. Skrinska}

\section{Santrauka}

Didžioji dalis šilumos vartotojų Vilniaus mieste šilumą gauna iš šilumos tinklų. Plačiausiai taikoma toliau aprašyta šilumos tiekiamoji schema. Iš šilumos šaltinio šiluma tiekiama iki centrinių šilumos punktų (CŠP) dvivamzde sistema. CŠP šildalas dalijasi į du srautus. Vienas naudojamas pastatams šildyti, o kitas karštam vandeniui ruošti. Vilniaus miesto šilumos tinklai yra uždari, todèl karštas vanduo ruošiamas greitaeigiuose vamzdiniuose šilumokaičiuose, kurie yra ịrengti CŠP, išskyrus tuos atvejus, kai šilumokaičiai irengti individualiuose vartotoju šilumos punktuose. Dèl to iš CŠP i vartotoju objektus yra pakloti keturiu vamzdžiu tinklai. Du iš ju skirti šildymo reikmèms tiekiamam šildalui, o kiti du - buitinèms reikmèms naudojamam karštam vandeniui.

Šilumos sąnaudos karšto vandens ruošimui yra labai glaudžiai susijusios su vonių patalpų šildymu rankšluosčiu džiovintuvais, kuriais teka buitiniams reikalams skirtas karštas vanduo. Tokiu būdu dalis karšto vandens šilumos nuo rankšluosčių džiovintuvy patenka ị voniu patalpas. Dẻl šios priežasties šilumos sąnaudos karšto vandens ruošimui negali būti analizuojamos neaptariant šildymo sistemos.

Šilumos sąnaudų tyrimui buvo pasirinktas vienas iš daugelio Vilnius miesto centrinių šilumos punktu, kuriame pagal specialiai šiems tyrimams parengtą metodiką buvo atlikti planuoti matavimai. Tyrimu metu debito ir šilumos skaitikliais buvo išmatuoti šildalo ir tiekiamo bei cirkuliacinio karšto vandens debitai ir suvartotos šilumos kiekiai šildymui ir karštam vandeniui ruošti. Duomenu kaupikliais šie dydžiai buvo registruojami viso tyrimo periodo metu, o po to perkelti ị kompiuterị ir apdoroti.
Nustatytos bendrosios šilumos sąnaudos karštam vandeniui, kurios vidutiniškai sudaro $96,75 \mathrm{kWh} / \mathrm{m}^{3}$, ir atskiri šių sąnaudu dèmenys: tik vandeniui sušildyti, vonių patalpoms šildyti ir šilumos nuostoliai skirstomuosiuose tinkluose bei pastate esančiuose vamzdynuose. Taip pat nustatytos vidutinès karšto vandens sąnaudos gyventojui per para bei karšto vandens vartojimas paros metu ir šilumos nuostoliai skirstomuosiuose vamzdynuose, kuriais šildalas teka î pastatu šildymo sistemas ir grižta iš ju.

Edvardas TUOMAS. Doctor, Associate Professor. Department of Heating and Ventilation. Vilnius Gediminas Technical University. Sauletekio al. 11, 2040 Vilnius, Lithuania.

Doctor (technical sciences), 1975. Associate Professor (1977-88) at the Department of Heating and Ventilation of Kaunas Polytechnic Institute (now Kaunas university of technology). Research visits to Civil Engineering Institute of Leningrad (at present St Petersburg) 1973, 1982), Company Asea Brown Boweri (ABB) in Denmark (1990), University of Glamorgan in UK (1992-1995), Company SFEE (France, 1995), Company Danfoss in Sweden, 1996. Co-author of a textbook and author over 50 scientific articles, 1 invention, 2 study guides, 1 Lithuanian Construction Code. Research interests: optimisation of air conditioning processes and district heating.

Alfonsas Kazys SKRINSKA. Doctor Habil, Professor. Department of Heating and Ventilation. Vilnius Gediminas Technical University, Sauletekio al. 11, 2040 Vilnius, Lithuania.

First degree (thermal engineering), Kaunas Polytechnic Institute (1958). Doctor (thermal engineering), Institute of Energy (Moscow, 1965). Doctor Habil (technological sciences), Lithuanian Energy Institute (1994). Associate Professor (1993). Professor (1996). Co-author of 4 books, author of 80 scientific articles, 20 inventions. Research interests: thermal engineering, heat transfer, thermotechnical processes in technology. 